\title{
ZBAWCZE ZNACZENIE WCIELENIA U TEODORA $Z$ MOPSUESTII
}

\begin{abstract}
„Jakie słowo lub jaka myśl zdołają oddać wielkość podanych nam tajemnic? Jaki język potrafi wyjaśnić te tajemnice? Przy pomocy naszego języka trudno jest już przedstawić to, co dotyczy nawet natur stworzonych, które z wielką mądrością uczynił Stwórca, a to, co przewyższa naszą naturę [...] czyż nie przekracza zdolności naszych słów?"
\end{abstract}

Teodor z Mopsuestii ${ }^{1}$.

1. Problemy z chrystologią Teodora $\mathrm{z}$ Mopsuestii. Chociaż synod konstantynopolitański z 394 r. stwierdził: „nie wydaje się, by potępienie zmarłego mogło być sprawiedliwe" ${ }^{2}$, i chociaż Constitutum papieża Wigiliusza z 14 maja 553 r. potępiało niektóre tylko zdania z pism Teodora z Mopsuestii ${ }^{3}$, a nie pamięć o nim, gdyż według Soboru Chalcedońskiego nie mógł być podejrzany o herezję, to jednak II Sobór Konstantynopolitański (553) - nawiązując do stanowiska Cyryla Aleksandryjskiego oraz opierając się na tendencyjnie sfałszowanym wyborze jego pism $^{4}$ - przystąpił do zdecydowanej rozprawy także z biskupem Mopsuestii, potępiając w czasie swojej VIII sesji 2 czerwca 553 r., słynne Tria Kephalaia, a przy okazji także jego samego. Dyskutowany wtedy problem dotyczył interpretacji Soboru Chalcedońskiego, koncentrując się wokół wyrażenia „w dwóch naturach”, które starano się ująć i wyrazić w relacji do ,jednej hipostazy”. W posiadanym streszczeniu obrad soboru i w jego kanonach znajdujemy przedstawienie całego problemu ${ }^{5}$, a streszczenie problematyki dotyczącej samego Teodora zostało zawarte w kanonie 12:

${ }^{1}$ Homilia catechetica I 1, wyd.: Les homélies catéchétiques de Théodore de Mopsueste. Reproduction phototypique du Ms. Mingana Syr. 561, trad. R. Tonneau en collaboration avec R. Devreesse, Studi e Testi (ST), Città del Vaticano 1949, s. 3, przekład W. Kania (w rękopisie).

${ }^{2}$ Por. C. J. Hefele - H. Leclercq, Histoire des conciles, II 1, Paris 1908, 99-100.

${ }^{3}$ Por. Constitutum de tribus capitulis, PL 69, 67-114.

${ }^{4}$ Por. L. Abramowski, Zur Theologie Theodors von Mopsuestia, ZKG 72(1961) 263-293. 
„Tak samo [niech będzie wyłączony ze społeczności wiernych] ten, kto broni bezbożnego Teodora z Mopsuestii, uczącego, że kim innym jest Bóg-Słowo, a kim innym Chrystus, który będąc podległym namiętnościom duszy i żądzom ciała, stopniowo wyzwalał się od rzeczy gorszych, aby stać się doskonalszym dzięki dobrym uczynkom i stał się [w końcu] bez skazy w swoim postępowaniu; jako zwykły człowiek został ochrzczony w imię Ojca i Syna i Ducha Świętego; przez chrzest otrzymał laskę Ducha Świętego, zasłużył na synostwo i na podobieństwo Królewskiego Wizerunku odbiera kult oddawany osobie Boga-Słowa, a po Zmartwychwstaniu stał się niezmienny w myślach i bezgrzeszny we wszystkim. Ten sam bezbożny Teodor powiedział jeszcze: Takie nastąpiło zjednoczenie Słowa z Chrystusem, jakie według Apostoła ma miejsce między mężczyzną a niewiastą: «utworzą dwoje jedno ciało»" [Ef 5, 31]..."

Zasadniczo więc sobór przypisuje Teodorowi, że jest zwolennikiem rozdzielenia dwóch natur w oparciu o affectualem unitatem $^{7}$, a w związku z tym oskarża go, iż „odrzucił wielkie misterium ekonomii naszego zbawienia" ${ }^{\text {. }}$.

Jednoznaczność potępienia soborowego dotyczącego doktryny Teodora z Mopsuestii oraz tych, którzy chcieliby ich bronić doprowadziła do tego, iż pisma jego zostały w większości zniszczone, a badania nad jego doktryną prowadzone w oparciu o pozostałe ich szczątki zostały podjęte dopiero w XX wieku, do czego przyczyniły się m.in. nowe odkrycia jego dzieł, które się szczęśliwie zachowały w thumaczeniach syryjskich. Ponieważ badania nad Teodorem są jeszcze dość skromne, dlatego wiele problemów dotyczących jego doktryny pozostaje nadal otwartych ${ }^{9}$. W niniejszym przyczynku zamierzam zwrócić uwagę na elementy chrystologii i soteriologii Teodora z Mopsuestii, jakie możemy wyprowadzić z jego dziesięciu homilii katechetycznych wygłoszonych do katechumenów o Symbolu Nicejskim. Korzystam tutaj z thumaczenia katechez z języka syryjskiego, jakiego dokonał ks. Wojciech Kania, a które jest obecnie przygotowywane do druku.

2. Kontekst. Aby uchwycić istotę problemu chrystologiczno-soteriologicznego u Teodora ${ }^{10}$, należy najpierw zwrócić uwagę na jego kontekst, na który

${ }^{5}$ Por. Sententia adversus ,,Tria Capitula”, Anathematismi adversus „,Tria Capitula”, Mansi IX 368-388, lub: Concilium Oecumenicorum Decreta, (= COD), Bologna 1991², 107-122.

"Anathematismi adversus „, Tria Capitula” 12, Mansi IX 383, lub COD 119, thum. Breviarium Fidei $(=B F)$. Wybór doktrynalnych wypowiedzi Kościota, oprac. S. Głowa - I. Bieda - J. M. Szymusiak, Poznań 1989, VI 22, s. 234.

${ }^{7}$ Por. Anathematismi adversus „Tria Capitula” 4, Mansi IX 379, COD 115: „, Theodori autem et Nestorii seguaces, divisione gaudentes, affectualem unitatem introducunt".

8 Por. Sententia adversus ,, Tria Capitula”, Mansi IX 371, COD 109.

${ }^{9}$ O Teodorze z Mopsuestii i jego teologii por. R. Devreesse, Essai sur Théodore de Mopsueste, ST 141, Città del Vaticano 1948.

${ }^{10} \mathrm{O}$ chrystologii Teodora z Mopsuestii por. E. Amann, La doctrine christologique de Théodore de Mopsueste (à propos d'une publication récente), RevSR 14(1934) 161-190; J. Mc W. 
składają się dwie składowe, a mianowicie składowa ogólnoteologiczna, skoncentrowana chrystologicznie, oraz składowa niejako osobista, mająca charakter religijno-duszpasterski. Jeśli chodzi o pierwszą składową kontekstualną, to trzeba zauważyć, iż teologia Teodora sytuuje się w ramach właściwej kwestii chrystologicznej, jaka wyłoniła się około połowy IV wieku oraz którą musiała podjąć i adekwatnie rozwinąć teologia wschodnia. Kwestia ta dotyczy ,jednego Chrystusa”, czyli natury samego wcielenia Boga. Trzeba tutaj oczywiście od razu podkreślić, że jest to problem specyficznie wschodni, gdyż Zachód nie był w niego szerzej zaangażowany, a ewentualne zainteresowanie wynikało bądź z innych przesłanek, bądź koncentrowało się na innych problemach. $\mathrm{Na}$ Wschodzie zagadnienie to zostało po raz pierwszy postawione na poziomie eklezjalnym na synodzie w Aleksandrii w 362 roku. Jego bezpośrednią przyczyną był kontrast, jaki zaistniał między uczniami Eustacjusza i uczniami Apolinarego. Kontrast ten przerodził się w głęboką i długotrwałą kontrowersję chrystologiczną, jaka osiągnęła swój przełom w 428 roku, a zwieńczenie na Soborze Chalcedońskim. Dwa zasadnicze kierunki tego sporu łączą się zasadniczo z dwoma stolicami biskupimi - Aleksandrią i Antiochią, stąd nazywa się je umownie kierunkiem aleksandryjskim i kierunkiem antiocheńskim. Czołowymi przedstawicielami pierwszego kierunku są Apolinary i Cyryl Aleksandryjski, a drugiego Diodor, Teodor z Mopsuestii, Jan Chryzostom, Nestoriusz i Teodoret ${ }^{11}$. Tradycja antiocheńska obejmuje także tradycję konstantynopolitańską, która jest jej bardzo pokrewna. Na zarysowanie się tych kierunków miały niewątpliwy wpływ także racje polityczne, gdyż chodziło o przeciwstawienie między dwoma stolicami biskupimi, to znaczy Aleksandrią i Konstantynopolem. Podczas gdy w Nicei drugie miejsce po Rzymie przyznano Aleksand-

Dewart, The notion of „Person” underlaying the christology of Theodore of Mopsuestia, ,Studia Patristica” 12(1975) 199-207; H. M. Diepen, L'Assumptus Homo à Chalcédoine, ,Revue Thomiste" 51(1951) 573-608; P. Galtier, Théodore de Mopsueste: sa vraie pensée sur l'incarnation, RechSR 45(1957) 161-186, 338-360; J. McKenzie, Annotations on the christology of Theodore of Mopsuestia, „Theological Studies” 19(1958) 345-373; N. el-Khoury, Der Mensch als Gleichnis Gottes. Eine Untersuchung zur Antropologie des Theodor von Mopsuestia, OrChr 74(1990) 62-71; J. M. Lera, Nuevas perspectivas en la cristología de Teodoro de Mopsuestia, MCom 31(1973) 79-124; K. McNamara, The Problem of Theodore of Mopsuestia, "The Irish Theological Quarterly" 24(1957) 175-184; tenze, Theodore of Mopsuestia and the Nestorian Heresy, tamze, 19(1952) 254278, 20(1953) 172-191; R. A. Norris, Manhood and Christ. A study in the christology of Theodore od Mopsuestia, Oxford 1963; P. Parente, Una riabilitazione di Teodoro di Mopsuestia, ,Doctor Communis" 1(1950) 3-15; G. H. M. Posthumus Meyies, De christologie van Theodorus van Mopsuestia, VoxTh 24(1953-1954) 153-164, 25(1954-1955) 9-22; M. Richard, La tradition des fragments du traité

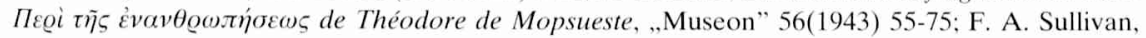
The Christology of Theodor of Mopsuestia, Roma 1956.

11 Por. T. Camelot, De Nestorius à Eutychès. L'opposition de deux christologie, w: Das Konzil von Chalkedon, red. A. Grillmeier - H. Bacht, Bd. 1, Würzburg 1951, 213-242; L. Abramowski, Der Streit um Diodor und Theodor zwischen den beiden ephesinischen Konzilien, ZKG 67(1955/56) 252-287. 
rii, to na Soborze w Efezie, a przede wszystkim potem w Chalcedonie, to Konstantynopol został postawiony zaraz po „starym Rzymie”12.

W kontrowersji tej była do pewnego stopnia zaangażowana także tradycja łacińska. Papież Damazy i Ambroży wystąpili przeciw apolinarystom, a papież Celestyn stanął po stronie Cyryla przeciw Nestoriuszowi. W końcowym etapie kontrowersji ważną rolę odegrał Leon Wielki ze swoim Tomus ad Flavianum ${ }^{13}$, który inspirował się chrystologią Augustyna, streszczającego tradycję łacińską $\mathrm{w}$ formule: una persona in utraque natura ${ }^{14}$. W ten sposób w Chalcedonie były już reprezentowane trzy tradycje, łączące się z trzema stolicami: Rzymem, Aleksandrią i Antiochią/Konstantynopolem.

Teodor jest więc przedstawicielem jednej z tradycji, które zostały poddane poniekąd definitywnej „obróbce” dopiero w Chalcedonie. Takie ustawienie sprawy mówi, iż nie należy oczekiwać, że u Teodora, czy też u innych przedstawicieli poszczególnych tradycji, będzie można znaleźć niejako ante litteram dogmat chalcedoński, z jego formułami i z adekwatnymi objaśnieniami. Tym, czego należy szukać, jest raczej ogólny obraz Jezusa Chrystusa, jaki przedstawiali oni wiernym w swoim kerygmacie, gdyż tylko w ten sposób można dobrze uchwycić treści ich chrystologii i soteriologii. Takie ujęcie pozwala także na właściwą interpretację dogmatu chalcedońskiego, a przede wszystkim na zachowanie w nim równowagi między znaczeniem dogmatycznym, a znaczeniem duchowym i pastoralnym. Wyjaśnienie dogmatyczne problemu chrystologicznego w Chalcedonie ma zasadniczo znaczenie pomocnicze, gdyż pierwszorzędnie służy on ukazaniu wymiaru religijnego i zbawczego w misterium Chrystusa, a więc odnosi się przede wszystkim do chrześcijańskiej praktyki. To jest właśnie ta składowa osobista, którą należy widzieć także u Teodora. Problem natury Boskiej i ludzkiej w Chrystusie oraz ich połączenia nie był dla niego przede wszystkim problemem filozoficzno-spekulatywnym i nie z tego punktu widzenia należy pierwszorzędnie interpretować jego teologię, jak również teologię Ojców i myślicieli zaangażowanych w spór w ramach trzech wspomnianych kierunków chrystologicznych. Jak pokazuje Homilia $V$, w której komentuje słowa: „Dla nas ludzi i dla naszego zbawienia”, Teodor jest skoncentrowany na wydobyciu zbawczego działania Boga w świecie, które osiąga punkt kulminacyjny w Jezusie Chrystusie i Jego pośrednictwie, a w Homilii $I X$ i $X$ zmierza do ukazania, że to działanie dokonuje się w mocy Ducha Świętego. Możemy więc powiedzieć, że punktem wyjścia kerygmatu Teodora jest doświadczenie soteriologiczne, czyli „efekt” zjednoczenia między Bogiem i Jezusem Chrystusem, poprzez które zamierza on ukazać skuteczny charakter Boskich działań

${ }^{12}$ Por. Concilium Nicaenum can. 6; Concilium Chalcedonense can. 28.

${ }^{13}$ Por. Tomus ad Flavianum (Epist. 28), PL 54, 755-779, thum. K. Tomczak, POK 24, ss. XXXVIII-XLIX.

${ }^{14}$ Por. B. Studer, Una persona in Christo. Ein augustinisches Thema bei Leo dem Grossen, „Augustinianum” 25(1985) 453-487. 
zbawczych. Ten realizm zbawczy jest związany z prawdziwym Bóstwem i prawdziwym człowieczeństwem Jezusa Chrystusa, które kilkakrotnie nazywa wprost „ekonomią”. W homiliach Teodor jawi się słuchaczowi jako człowiek dogłębnie religijny i praktyczny, który czuje fakt, że herezje - przede wszystkim herezja ariańska, która jest jakby tłem jego refleksji - narażają na niebezpieczeństwo zbawienie człowieka w Jezusie Chrystusie. Jeśli Chrystus nie byłby „od wieczności” prawdziwym Bogiem, to znaczy z Jego natury (homoousios), o czym traktują szeroko Homilie od $I$ do $I V$, to nie byłby reprezentantem Boga, ale stworzenia ${ }^{15}$, nie mógłby doprowadzić do „poznania prawdziwego Boga”, nie mógłby wprowadzić człowieka na drogę życia, by stał się ,cząstką Chrystusa" ${ }^{17}$ i osiągnął „nieśmiertelność i niezniszczalność”18. Bóstwo Chrystusa działające w przyjętym człowieku jest więc warunkiem i drogą do komunii człowieka z Bogiem, a więc decyduje o jakości i pewności zbawienia. W taki sposób problematyka dotycząca zbawienia człowieka stanowi kontekst bliższy kerygmatu Teodora.

3. Podstawy. Pierwszą kwestią, jaką należy zauważyć w homiliach Teodora jest troska o ortodoksję, czego wyrazem jest zdecydowana akceptacja Credo nicejskiego ${ }^{19}$. W całym swoim nauczaniu uwzględnia on polemikę z Ariuszem, Eunomiuszem i Apolinarym, wykazując ograniczenia i błędy zawarte w ich herezjach. W ramach swojego wykładu opiera się na chrystologii, która jest powszechnie określana mianem doktryny homo assumptus, chociaż lepiej byłoby ją określać mianem doktryny Deus assumens et homo assumptus. Wskazuje na to wyraźnie sam Teodor w VIII homilii, w której znajdujemy takie oto stwierdzenie:
„Nie był On [Jezus Chrystus] tylko Bogiem, ani tylko człowiekiem. Ten, który jest postacią Boga, przyjął postać sługi. Nie był On ani tylko Bogiem, ani tylko czło- wiekiem, lecz przez naturę jest w obydwóch; jest zarówno Bogiem, jak i człowie- kiem. On jest Bogiem Słowem - On jest tym, który przyjmuje i On jest człowie- kiem, który został przyjęty; On, który został przyjęty nie był tym, który Go przyjąl. Raczej ten, który przyjmuje jest Bogiem, podczas gdy ten, który został przyjęty jest człowiekiem"20.

Stwierdzenia powyższe oznaczają, że Teodor na pierwszym miejscu postawił jasne rozróżnienie między naturą Boską i naturą ludzką, tak że słusznie jego

15 Por. Homilia III.

${ }_{16}$ Homilia II 3, ST 145, 33.

17 Homilia I 4, ST 145, 9.

18 Homilia I 3, ST 145, 7.

19 Por. S. Gerber, Theodor von Mopsuestia und das Nicaenum. Studien zu den katechetischen Homilien, Leiden 2000; A. Mingana, Commentary of Theodore of Mopsuestia on the Nicene Creed, Cambridge 1932.

${ }^{20}$ Homilia VIII 1, ST 145, 187; por. także VIII 5 i 10. 
chrystologia mogła zostać nazwana „chrystologią paralelną” bądź „rozdzielającą" ${ }^{21}$. Ze względu na szacunek dla transcendencji Boga stara się on wykluczyć wszelkie pomieszanie między tym, co Boskie i tym, co ludzkie. Z tego powodu okazuje się między innymi dość oględny w odniesieniu do takich wyrażeń, jak „Bóg stał się człowiekiem”, „Boża Rodzicielka”22, i podobnych $^{23}$. Nazywa więc Chrystusa najczęściej „Synem” lub „Panem”.

Jeśli chodzi o Janowe „Słowo stało się ciałem”, to zwraca uwagę, iż nie oznacza ono zmiany, ale „zamieszkiwanie”, dzięki któremu zewnętrznie upodabnia się On do człowieka. Jezus nie był więc człowiekiem pospolitym, chociaż wydawało się, że nim jest ${ }^{24}$. Mimo tego przeciwstawienia między Bóstwem i człowieczeństwem, z oczywistym pierwszeństwem danym prawdziwemu Bóstwu, Teodor nie lekceważy „ekonomii człowieczeństwa”, przedstawiając Jezusa jako człowieka integralnego, $\mathrm{z}$ ciałem i duszą, a więc człowieka w sensie pełnym $^{25} . \mathrm{Z}$ tej integralnej wizji nie wyklucza także voũ 5 , któremu nadaje realne znaczenie, będące miejscem wolności i grzechu Adama, gdyż jest ono miejscem, w którym dokonało się decydujące zwycięstwo nad Szatanem ${ }^{26}$. Ponieważ grzech człowieka ma początek w aktach woli, dlatego Chrystus musiał też przyjąć ludzki voũs. Wydaje się, że istnieje tu nawiązanie do idei wymiany według przypisywanego św. Atanazemu principium: Quod non est assumptum non est sanatum ${ }^{27}$.

Dokonując pełnego rozróżnienia natury Boskiej i ludzkiej w Jezusie Chrystusie oraz podkreślając znaczenie Jego pełnego człowieczeństwa, Teodor troszczy się równocześnie o zapewnienie właściwego i nienaruszalnego miejsca jedności Boga-Człowieka. Trzeba tu zauważyć, że w „odgórnej” tradycji aleksandryjskiej, opartej na schemacie Logos/sarx, ta jedność była podstawowym założeniem teologicznym, podczas gdy u Teodora nie jest to takie oczywiste. Jest to dla niego niewątpliwie kwestia istotna, ale która musi zostać dopiero wypracowana „oddolnie” na gruncie rozróżnienia natur, czyli poniekąd stanowi punkt dojścia jego chrystologii. Podejmując to zagadnienie, Teodor wyklucza więc najpierw tezę jakoby mogło być dwóch synów albo dwóch Chrystusów ${ }^{28}$, i pozytywnie przechodzi do wyrażenia koncepcji jedności, z jaką mamy do czynienia w tym przypadku. Ponieważ Bóg w swoim bycie, jak i swoim działaniu jest wszechobecny, dlatego też ten sposób obecności nie może być

${ }^{21}$ H. Pietras, Początki teologii Kościoła, Kraków 2000, 216.

22 Por. Contra Apollinarem, PG 66, 993; De incarnatione 15, PG 66, 992.

23 Homilia VI 3; VIII 5 i 16, ST 145, 135, 193 i 209.

${ }^{24}$ Por. Homilia V 7; VI 3.

25 Por. Homilia V 11, 15n.

${ }^{26}$ Por. Homilia V 9-17; VI 10.

27 Por. Athanasius, Tomus ad Antiochenos 7, PG 26, 804B; Gregorius Nazianzenus, Epistula 101 (Ad Cledonium I), PG 37, 181C-184A; A. Grillmeier, , Quod non assumptum, non sanatum”, LThK VIII ${ }^{2}$ 954-956.

${ }^{28}$ Por. Homilia VIII $14 \mathrm{n}$. 
podstawą do wyjaśnienia Jego szczególnej obecności w Chrystusie ${ }^{29}$. Pozytywnie więc jego odpowiedź idzie w kierunku przyjęcia jedności w oparciu o „upodobanie” Boże i przez pośredniczenie Ducha Świętego, to znaczy „przez laskę”, jak streści to ujęcie Sobór Florencki ${ }^{30}$.

W tym miejscu sytuuje się podstawowy punkt właściwej kontrowersji dotyczącej chrystologii Teodora. Zarówno teologowie starożytni, jak i współcześni zarzucają mu, że rozumiał on jedność Chrystusa w sensie czysto moralnym, różniącą się tylko stopniem od zjednoczenia, jakie zachodzi w przypadku relacji człowieka sprawiedliwego z Bogiem ${ }^{31}$. Rzeczywiście, opisuje on zjednoczenie natur w Chrystusie przy pomocy kategorii moralnej synapheia, oznaczającej więź miłości. Chociaż zwraca ponadto uwagę, że w tym zjednoczeniu Słowo nie mieszka jak w proroku, i że należy mówić o tym zjednoczeniu raczej przy pomocy określenia ,jak w synu”, to jednak nie ma u Teodora spójnego rozwinięcia tego zagadnienia ${ }^{32}$. Trzeba jednak zaznaczyć, że nie da się ostatecznie ustalić, czy te kategorie moralne mają tylko i wyłącznie charakter moralny. Zjednoczenie Jezusa ze Słowem zostało zapoczątkowane $\mathrm{w}$ chwili poczęcia w łonie matki i jest ono nierozerwalne; to zjednoczenie, jako świętość dobrowolnie chciana, jest nienaruszalne, ponieważ udzielanie się Słowa na trwałe zachowało ludzką wolność Jezusa od wszelkiej skłonności do złego. Jezus został obdarowany pełnią Ducha Świętego, którego ludzie otrzymują w sposób częściowy. Aby wyrazić to zjednoczenie Teodor często odwołuje się do obrazów „zamieszkiwania”, „przyjęcia”, „świątyni”, w nawiązaniu do J 2, $19^{33}$, oraz „płaszcza królewskiego”, które były znane zarówno w tradycji antiocheńskiej, jak i aleksandryjskiej.

Własny wkład Teodora zawiera się w trzech ściśle ze sobą połączonych zagadnieniach: - synostwo; - uczestniczenie w godności, wszechmocy i godnoś-

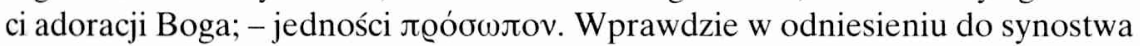
jeden raz używa pojęcia adopcji, ale równocześnie nie dopuszcza dwóch synów. Chociaż tylko Słowo jest Synem przez naturę i prototyp, to jednak człowiek Jezus uczestniczy w autentycznym synostwie przez laskę i przez pochodzenie prototypu. Teodor wydaje się zbliżać do poglądu, że przyjęty człowiek zostaje podniesiony przez łaskę do naturalnego synostwa Słowa - nie jest więc drugim synem obok pierwszego. Na mocy pełnej komunii przez jego przyjęcie, człowiek wchodzi w szczególną relację Syna Bożego z Ojcem i może powiedzieć: „przez moje zjednoczenie z Bogiem Słowem jestem Synem”34. Mimo to wy-

${ }^{29}$ Por. De incarnatione 7, PG 66, 972-975.

${ }^{30}$ Por. Bulla unionis Coptorum, COD 574: „Anathematizat etiam Theodorum Mopsuestenum atque Nestorium asserentes humanitatem Dei Filio unitam esse per gratiam”.

${ }^{31}$ Por. Homilia V 5-6.

32 Por. Homilia VI $3 ; 8,10$.

33 Por. Homilia VIII 5.

${ }^{34}$ Commentarius in Evangelium Joannis: CSCO 116, 145. 
rażenie Pisma Świętego: „Dał swojego Syna Jednorodzonego” wywołuje u Teodora trudności: nie Syn, który nie cierpi, zostaje wydany na śmierć, ale „inny”; jednak z powodu więzi, jaka zachodzi między dwoma, wszystko zostaje przypisane Bóstwu ${ }^{35}$. Dwuznaczność Teodora może być rozwiązana w następujący sposób: stwierdza on podniesienie natury ludzkiej w naturze Bożej, ale powstrzymuje się od uznania głębokiego zaangażowania Syna Bożego w człowieczeństwie.

Przyjęcie w Słowie Bożym prowadzi w człowieku do wyniesienia nadprzyrodzonego, uczestniczenia w Jego czci, w Jego godności przybrania, w Jego powszechnym panowaniu i wszechmocy. Na pytanie, co to znaczy, że Słowo mieszka w człowieku ,jak w synu", Teodor odpowiada:

„Słowo tak w nim mieszkało, że jednoczyło Ono w pełni z sobą tego, który został przyjęty, uzdalniając Go w ten sposób do uczestniczenia w wszelkiej czci, w której ten, który zamieszkuje, uczestniczy jako Syn przez naturę; w taki sposób On, na

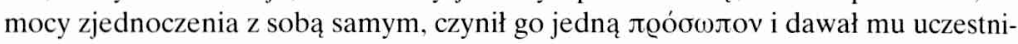
czenie we wszelkiej władzy; On dokonywał wszystkiego w nim tak, że on, przez Niego i przez Jego paruzję, dokonuje także sądu nad każdą rzeczą" ${ }^{36}$.

Pojęcia takie jak „cześć” i ,adoracja” mogą sugerować, że Jezus byłby Bogiem wyłącznie dla nas ludzi, ale w ich pozycji paralelnej do pojęć „,powszechnego panowania” i „wszechmocy” pojęcia te niewątpliwie mają treść bardziej realną. Człowiek jest synem także dla Ojca; rzeczywiście, otrzymał on chwałę w chwili zmartwychwstania, ale „godność” należała się mu już wcześniej. Mamy w teologii Teodora do czynienia z pewnymi paradoksami; między innymi, aby uniknąć wszelkich pozorów subordynacjonizmu, odrzuca on odniesienie do natury Bożej słów Ewangelii, w których Jezus mówi, że otrzymuje coś od Ojca ${ }^{37}$, przy czym jest równocześnie zmuszony do uznania skrajnego przebóstwienia człowieka. „Wszechmoc” w rygorystycznej teologii zjednoczenia nie jest własnością natury ludzkiej, a władza człowieka, by wyrzec się własnego życia i by je odzyskać, oznacza niebezpieczną destrukcję autentyczności jego umierania.

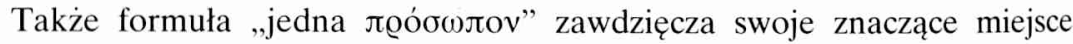
w chrystologii greckiej Teodorowi z Mopsuestii, chociaz u niego samego nie odgrywała jeszcze decydującej roli w wyjaśnieniu misterium Chrystusa i jest

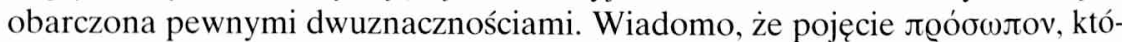
re pierwotnie oznacza „maskę” lub „rolę do odegrania”, weszło do teologii trynitarnej w IV wieku. Najpierw budziło podejrzenia z tego powodu, iż wydawało się sugerować jakoby Ojciec, Syn i Duch Święty byli tylko różnymi

\footnotetext{
${ }^{35}$ Por. tamze, CSCO 116, 51-52.

36 De incarnatione 7, PG 66, 976.

37 Por. Commentarius in Evangelium Joannis, CSCO 116, 163.
} 
rolami odgrywanymi przez jednego i tego samego Boga, jednak z biegiem czasu

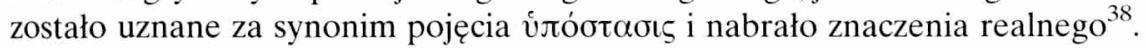
W doktrynie trynitarnej było używane także przez Teodora, chociaż pojawia się pytanie czy miało takie samo znaczenie w jego chrystologii - i trzeba przyznać, że tutaj budzą się różne wątpliwości.

Teodor początkowo mówi o osobowości tylko wtedy, gdy jest do tego niejako przymuszony. Dzieje się tak w tych przypadkach, gdy Pismo Święte lub nicejskie Credo zmuszają go do uznania, że Jezus mówi jako Bóg i jako człowiek - jako Syn Boży i Syn Maryi - jako jeden podmiot. Schemat dwóch natur dominuje całkowicie nad jego myślą do tego stopnia, że stwierdzenia tego typu stawiają go wobec niepokonalnych trudności, chociaż przyznaje, iż są to stwierdzenia „prawdziwe”. Inną wątpliwość budzą porównania, przy

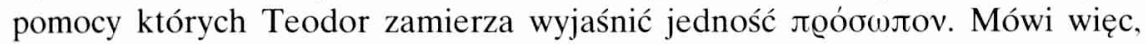
że ta jedność jest taka, jak jedność mężczyzny i kobiety - są oni dwojgiem ludzi, a jednak są jednym ciałem, bądź taka, jak jedność człowieka wewnętrznego i zewnętrznego - różnią się między sobą, a jednak są tym samym bytem ludzkim. W taki sam sposób w Chrystusie Bóg, który przyjmuje, i człowiek, który zostaje przyjęty, są dwoma, jeśli analizujemy ich naturę, ale są jednym, gdy patrzymy na ich więź. Te porównania nie wnoszą jednak niczego do rozwiązania problemu.

Jeśli chodzi o chrystologię Teodora z Mopsuestii, to łatwo widzimy u niego dążenie do możliwie najgłębszego wyrażenia jedności syna człowieczego z Synem Bożym. Skłania go do tego znajomość Pisma Świętego, jego wrażliwość religijna oraz jego formacja. Że rzeczywiście chciał być ortodoksyjny, wynika $\mathrm{z}$ wielu faktów, zwłaszcza z bezwarunkowego uznania Symbolu Nicejskiego za kryterium ortodoksji. Poza tym opierał się - jak się wydaje - na uznanych wówczas autorach, jakimi byli Ojcowie Kapadoccy i Dydym. Jego synteza zawiera elementy, które wykorzysta później Sobór Chalcedoński, i które ciągle są warte refleksji. Mimo to wydaje się jednak, że jego ujęcie pozostaje problematyczne. Jakkolwiek by nie interpretować tego, co mówi

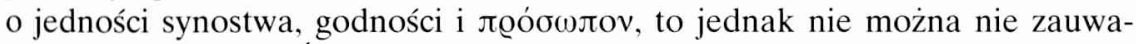
żyć, że teksty Pisma Świętego mówiące o tej jedności stawiają go często wobec trudności i ich interpretacja nie jest jednoznaczna. Jak u jego poprzedników antiocheńskich, takie teksty stają się raczej pytaniami, niż źródłami odpowiedzi. Nierzadko poświęca swoją wierność Pismu Świętemu na rzecz takiej interpretacji, która jest dla niego wygodniejsza. Różnica natur zajmuje u niego do tego stopnia pierwsze miejsce, że nie może powiedzieć, iż Syn Boży jest ,,jeden i ten sam" z Synem Maryi. W polemice z Apolinarym takie stwierdzenie było

${ }^{38}$ Por. A. de Halleux, „Hypostase” et „Personne” dans la formation du dogme trinitaire (ca. 375-381), RHE 79(1984) 313-369, 625-670; A. Milano, Alle origini del significato di persona nel cristianesimo antico, Roma $1996^{2}, 53-59$. 
konsekwentnie odrzucane. Było to związane także z coraz bardziej dominującą rolą, jaką dwoistość natur nabrała w ciągu IV wieku w chrystologicznej tradycji antiocheńskiej.

4. Zbawienie. Słowo Boże - Słowo stworzenia i Słowo zbawienia - stało się człowiekiem dla ludzi i doświadczyło w pełni ludzkiego losu; ponieważ każdy człowiek jest wyrażony i powołany przez to Słowo, dlatego ten człowiek na mocy doskonałego zjednoczenia z tym Słowem jest człowiekiem doskonałym; Bóg objawia siebie w tym człowieku, prowadząc wszystkich do siebie - takie konsekwencje wyprowadziła najbardziej pierwotna chrystologia z refleksji nad tym faktem, że Słowo stało się ciałem. Szczególnie mocno wyraziły się te konsekwencje w „odgórnej” chrystologii aleksandryjskiej. Skoro u Teodora stwierdzenie św. Jana: „Słowo stało się ciałem”, które stanowiło podstawę starożytnej soteriologii, nie odgrywało decydującej roli, to pojawia się cały szereg znaczących pytań pod adresem wymiaru soteriologicznego w jego interpretacji misterium wcielenia, przy czym - jak już wspomniano - obecność tego wymiaru także u niego jest dominująca.

Idąc po linii doktryny homo assumptus Teodor rozwija i wyjaśnia swoją koncepcję Misterium Paschalnego jako przejścia z czasu niedoskonałości do czasu doskonałości. Według tej koncepcji homo assumptus, prowadzony przez Słowo za pośrednictwem łaski Ducha Świętego doszedł do nowego stanu, jeśli chodzi o jego ciało i duszę ${ }^{39}$. Przejście do życia w zmartwychwstaniu jest rozumiane w podwójny sposób - jako zwycięstwo nad śmiercią i grzechem, przy czym sam Jezus nie jest wolny od pokus i doświadczeń. Wszystko to oczywiście dokonuje się „dla nas i dla naszego zbawienia”. Jego przejście do drugiego porządku (katastasis) stanowi więc początek i gwarancję naszego przejścia $^{40}$. Zbawcze znaczenie przyjętego człowieczeństwa ma u Teodora jednak jeszcze konkretniejsze znaczenie. Według niego ostateczne zbawienie urzeczywistnia się wyłącznie w drugim czasie, gdy nie będzie już ani śmierci, ani grzechu, a odkupieni będą synami Ojca w Duchu Świętym ${ }^{41}$. Wszystko to jednak jest możliwe tylko w komunii z homo assumptus, który osiągnął już nieśmiertelnośćc ${ }^{42}$.

Homo assumptus był obrazem chrześcijan nie tylko w swoim Misterium Paschalnym, ale w całym swoim ziemskim życiu, przede wszystkim w swoim nastawieniu pełnym nadziei na życie wieczne ${ }^{43}$. Jest szczególnie ważne, że homo assumptus, stawszy się najwyższym kapłanem w swojej śmierci i zmartwychwstaniu wchodzi na stałe do nieba dla nas, i że wierni uczestnicząc

\footnotetext{
${ }^{39}$ Por. Homilia V 20; VII 4-9.

40 Por. Homilia V 11; XII 6.

${ }^{41}$ Por. Homilia X 20; XVI 26.

${ }^{42}$ Por. Homilia VII 10n.

43 Por. Homilia VI 1 i 11n.; VII 9.
} 
w Eucharystii uczestniczą w jego liturgii niebieskiej ${ }^{44}$, a tym samym dostępują osobistego zbawienia ${ }^{45}$. Wszystkie te stwierdzenia soteriologiczne odnoszą się przede wszystkim do homo assumptus. Dla Teodora u ich podstaw znajduje się zasadniczo podstawowa idea dotycząca Boga, a mianowicie, że tylko On sam jest Zbawicielem w swoim Synu. Przejście do drugiej epoki jest rzeczywiście dziełem Syna Bożego. Syn - Deus assumens - doprowadził do pełni homo assumptus. W tym sensie Teodor wyjaśnia Hbr 2, 10: „Udoskonalił Go przez cierpienie", jak również tekst z J 2, 19, dotyczący odbudowania świątyni w trzecim dniu ${ }^{46}$.

Dzieło Syna jest dla Teodora dziełem całej Trójcy Świętej. Ojciec podjął inicjatywę zbawczą, Duch Święty konsekrował Chrystusa w Jego misji oraz jest stale blisko chrześcijan ze swoją łaską ${ }^{47}$. Przede wszystkim jednak sam Syn działa zawsze w komunii z Ojcem i Duchem Świętym dla zbawienia ludzi ${ }^{48}$. Pokazuje się tutaj, że doktryna soteriologiczna Teodora jest zasadniczo oparta na antyariańskiej doktrynie wspólnego działania Ojca, Syna i Ducha Świętego.

Analizując chrystologię, jak i soteriologię u Teodora z Mopsuestii oraz $\mathrm{u}$ innych przedstawicieli tradycji antiocheńskiej łatwo zauważamy, że mamy tu do czynienia z refleksją teologiczną opartą na pryncypium transcendencji misterium Boga, które wyraża się nieufnością w stosunku do ujęcia jedności Chrystusa w oparciu o schemat Logos/sarx, a w soteriologii do jej wymiaru ontologicznego. Antiocheńczycy ujmowali życie chrześcijańskie nie tyle jako przebóstwienie przez Słowo, które stało się ciałem, i jako wyzwolenie z ciała poddanego upadkowi, co raczej jako zjednoczenie całego człowieka z Bogiem i jako zwycięstwo wewnętrzne nad grzechem. Stąd u Teodora szczególne znaczenie zostało nadane wyzwoleniu duszy od wszelkich grzesznych poruszeń ${ }^{49}$ oraz realizacji wzorów ewangelicznych ${ }^{50}$. Chrystus zjednoczony z Ojcem pozostaje wzorem chrześcijanina ${ }^{51}$. Homo assumptus stanowi więc przede wszystkim przykład zjednoczenia z Bogiem. Zjednoczenie w Chrystusie oznacza dla Teodora synapheia - więź miłości, w której uczestniczy ochrzczony i przez którą on również jednoczy się z Ojcem i Synem. Mamy więc u Teodora wybitnie moralną wizję zbawienia.

44 Por. Homilia XV 16.

45 Szerzej o urzeczywistnianiu się zbawienia według Teodora por. G. Koch, Die Heilsverwirklichung bei Theodor von Mopsuestia, München 1965.

46 Por. Homilia VIII 5-9.

47 Por. Homilia II 10-19; X 7-14.

48 Por. Homilia VIII 17.

49 Por. Homilia V 10n.

50 Por. Homilia VI 2 i 10.

51 Por. Homilia X 18. 


\section{IL SENSO SOTERIOLOGICO DELL'INCARNAZIONE IN TEODORO DI MOPSUESTIA}

(Riassunto)

Nella cristologia Teodoro di Mopsuestia rappresenta la tradizione antiochena. La sua riflessione non è priva di difficoltà interpretative ma egli non ha mai trascurato la preoccupazione per la retta fede. In tutta la sua predicazione tiene presente la polemica contro Eunomio e Apollinare. Egli difende sempre una cristologia che può essere considerata come dottrina dell'homo assumptus o meglio come dottrina del Deus assumens e dell'homo assumptus. Con ciò si evidenzia come in Teodoro la chiara distinzione tra natura divina e umana stia in primo piano..

Nella linea della dottrina dell'homo assumptus la soteriologia di Teodoro è incentrata sul Mistero Pasquale che spiega come il passaggio da questo tempo dell'imperfezione alla perfezione. Secondo questa concezione l'homo assumptus, guidato dal Logos mediante la grazia dello Spirito Santo, giunge ad un nuovo stato sia per quanto riguarda il corpo che l'anima. La soteriologia di Teodoro ha carattere tipicamente morale. 